\title{
EFFECT OF AZOTOBACTER AND AZOSPIRILLUM ON GROWTH AND YIELD OF RICE GROWN ON TIDAL SWAMP RICE FIELD IN SOUTH KALIMANTAN
}

\author{
Fakhrur Razie ${ }^{1}$ and Iswandi Anas ${ }^{2}$ \\ ${ }^{1}$ Department of Soil Science, Faculty of Agriculture, Lambung Mangkurat University \\ J1. A. Yani KM.36 Banjarbaru 70714, South Kalimantan \\ email: fakhrurrazie@yahoo.com \\ 2Laboratory of Soil Biotechnology, Faculty of Agriculture, Bogor Agricultural University (IPB). \\ Kampus IPB Darmaga, 16680 Bogor, West Java
}

\begin{abstract}
Tidal swamp land is a potential area for rice cultivation. However, tidal swamp is fragile ecosystems, so that when this area is used for rice cultivation, it has to be done carefully. To reduce a risk of environmental pollution in the tidal swamp area due to rice cultivation, the area should be managed properly and wisely especially when using agrochemicals such as fertilizers and pesticides. In relation to this, the use of bio-fertilizer such as Azotobacter or/and Azospirillum, an atmospheric nitrogen fixing bacterium, might be an important thing for this area. The objectives of this study were to evaluate the number of NFB (i.e. Azotobacter and Azospirillum spp.) found in tidalswamp rice fields of South Kalimantan, and their ability in fixing atmospheric nitrogen and supplying this fixed nitrogen to rice, and in increasing rice yields. There were three research stages performed in this study. The first, collecting, isolating and purifying the NFB on the selective media of nitrogen free media. The second, a hydroponic experiment in the greenhouse using Yoshida nutrition solution (Yoshida et al., 1976 in IRRI, 2003) as culture media and selected Azotobacter and Azospirillum. The third experiment was to study the effect of selected Azotobacter isolates to increase growth and yield of IR64 and Margasari rice cultivars, and two Azotobacter isolates were combined with six inoculation methods for Siam Unus rice cultivar as treatments. The result showed that the number of NFB strains found in rhizospere rice cultivars were varied widely. Then, Azotobacter and Azospirillum spp selected from rice fields in the tidal land of South Kalimantan when associated with IR64 and Siam Unus rice cultivars have ability in fixing atmospheric $N 2$ and in supplying $N$ on the initial rice growth. Azotobacter T.B.PDST.2b and T.HM.BPMT.2b were significantly supplying $N$ for early growth of IR64 rice cultivars $(2.34$ and $2.13 \% N)$. The ability of these isolates to fix atmospheric $\mathrm{N}_{2}$ was similar to $\mathrm{N}$ fertilizer (urea) in supplying $N(2.2 \% \mathrm{~N})$. Only Azotobacter T.B.PDST.2b was relatively significant to supply $N(1.36 \% \mathrm{~N})$ for Siam Unus rice cultivar early growth, even though this strain has less ability than $N$ fertilizer $(1.94 \% N)$ in supplying $N$. Azotobacter isolates grow in media containing no urea were higher IAA produced than in media containing Urea. Furthermore, yield of IR64, Margasari and Siam Unus inoculated with Azotobacter isolates were 3.87-4.93; 4.63-5.36 and 5.44-6.42 ton/ha respectively. In conclusion, the utilization of Azotobacter and Azorpirillum spp to substitute $N$ fertilizer would be able to increase effeciency of $N$ nutritions and to avoid environment pollutions risks from agrochemical $N$ fertilizer other than to increase rice yields on tidal land of South Kalimantan.
\end{abstract}

Keywords: Azotobacter, Azospirillum, rice cultivars, tidal lands and rice yields.

\section{INTRODUCTION}

In South Kalimantan, tidal swamp area is used for rice cultivation. This swampy area is a very fragile ecosystem. Therefore, application of agrochemicals such as synthetic fertilizer i.e. Urea, SP-36 and $\mathrm{KCl}$ as well as pesticide should be done carefully. So far, the use of Urea fertilizer with very high dosage has caused environmental pollution. Up-take efficiency of nitrogen fertilizer in this area is low. According to Biswas et al. (2000), up-take efficiency of Urea in tidal swamp area was reported to be much less than $50 \%$ (Biswas et al., 2000). On the other hand, recently there were tremendous increase in price of synthetic fertilizer such including Urea, SP-36 and $\mathrm{KCl}$. Application of bio-fertilizer, organic fertilizer, or combination of both (bio-organic fertilizer) might reduce the dosage of synthetic fertilizer applied, hence reduce the cost of production (input) as well as reduce the environmental problems.
Many reports have been published on the potential of Azotobacter and Azospirillum as bio-fertilizer in relation to their ability to fix atmospheric N2 and to produce plant growth promoting substances (i.e. indole acetic acids IAA). Both nitrogen fixing bacteria supply nitrogen to the pant and stimulate the growth of rice roots system and increase rice yield

The objectives of this study were (1) to determine the number of atmospheric nitrogen (N2) fixing bacteria (NFB) i.e. Azotobacter and Azospirillum spp. in the tidal land rice fields of South Kalimantan; (2) to isolate and selected these $\mathrm{N} 2$ fixing bacteria, and (3) to determine their ability to supply nitrogen to the rice plant, (4) to evaluate the effect of Azospirillum and Azotobacter on growth and yield of rice grown on tidal land area rice field area in South Kalimantan. 


\section{MATERIALS AND METHODS}

Three stages of research were performed in studying the NFB on tidal land rice fields of South Kalimantan. The first study was conducted to evaluate the number of NFB on tidal lands rice field of South Kalimantan and to determine effectiveness of selected NFB in fixing atmospheric $\mathrm{N}_{2}$ in culture medium. Soil and rhizosphere of rice plant samples were collected from several sites where three local rice cultivars (Bayar Pahit, Siam Pandak and Siam Unus), one high yield local rice cultivar (Margasari) and one national high yield rice cultivar (IR64) were grown. Isolating and purification of the NFB was carried out at the Soil Laboratories, Faculty of Agriculture, Lambung Mangkurat University. These bacteria were isolated using the selective media of Nitrogen Free Media (NFM) for Azotobacter and Nitrogen Free Bromthymol Blue (NFB) for Azospirillum (Atlas, 1997). The effectiveness of these bacteria to fix atmospheric N2 was determined in culture medium according to nitrogenase activities (Zuberer, 1998). Total nitrogen in the culture media was measured by using the Micro Kjeldahl methods and the nitrogenase activities was measured according to Acethylene Reduction Assay (ARA) value using Gas Chromatographic (Anas, 1999).

The second study was a hydroponic experiments. The purpose of this study was to evaluate the ability of the selected BNF to fix atmospheric $\mathrm{N}_{2}$ and to supply this fixed nitrogen to rice seedling. This experiment was conducted at the greenhouse of the Faculty of Agriculture IPB Dramaga Bogor. Nine isolates of Azotobacter and Azospirillum were tested. As a control, two treatments were performed i.e. Urea fertilizer and without urea or isolates) The treatments had three replications. Two rice cultivars (IR64 and Siam Unus) were used in this experiment. The hydroponic medium was Yoshida nutrition solution without $\mathrm{N}$ nutrient (Yoshida et al., 1976 in IRRI, 2003). The nutrient solution consisted of $\mathrm{NaH}_{2} \mathrm{PO}_{4} \cdot 2 \mathrm{H}_{2} \mathrm{O}(0.37 \mathrm{mM})$, $\mathrm{K}_{2} \mathrm{SO}_{4}(0.5 \mathrm{mM}), \mathrm{CaCl}_{2}(1.00 \mathrm{mM})$, and $\mathrm{MgSO}_{4} \cdot 7 \mathrm{H}_{2} \mathrm{O}(1.6$ $\mathrm{mM})$. The ability of isolates in fixing atmospheric $\mathrm{N}_{2}$ measured based on the difference in total Nitrogen content (total of plant $\mathrm{N}+\mathrm{N}$ in solution) between the inoculated treatments and uninoculated treatment.

The third experiment was the field experiments. The aim of this study was to evaluate the ability of selected Azotobacter isolate to increase the plant growth and to increase rice yield. The experiments was conducted at the Rice Research Stations of the Faculty of Agriculture, University of Lambung Mangkurat, Sungai Rangas-Banjar Regencies, South Kalimantan. A completely randomized block design experiments was performed. Three rice cultivars used in this experiment were IR64, Margasari and Siam Unus. Two selected Azotobacter were tested using IR64 cultivar and two selected Azotobacter were also tested using Margasari rice cultivar. The treatments were arranged in 30 plots $\left(5 \times 5 \mathrm{~m}^{2}\right)$ with three replication for IR64 and 36 plots $\left(5 \times 5 \mathrm{~m}^{2}\right)$ with three replication for Siam Unus rice cultivar.

\section{RESULTS AND DISCUSSION}

\section{The presence of Azotobacter and Azosprillum in the soil and rhizophere of ricegrown on tidal swamp rice field of South Kalimantan}

The numbers of Azotobacter and Azospirillum isolated from A type of tidal land (on Balandean fields) was seven Azotobacter and 16 Azospirillum, whereas in B and C types (Handil Manarap and Handil Malintang fields) as much as 12 and 14 Azotobacter; 23 and 22 Azosprillum isolates were found respectively. The numbers of Azotobacters isolates from Siam Pandak, Bayar Pahit, Sian Unus, Margasari IR64 rice cultivars were. 13, 12, 8, 5 and 4 Azotobacter isolates respectively. On the other hand, the number of Azospirillum isolated from Bayar Pahit, Siam Unus, Siam Pandak, IR64, Margasari rice cultivars were 27, 22, 20, 13 and 7 Azospirillum isolates respectively. This means that the number of Azotobacter and Azospirillum depent on the type of tidal swamp area (Type A, B or C) and rice cultivars.

The influence of sea water on soil properties is shown by electrical onductivity (EC) of soils. The EC value of Balandean soils (i.e. $0.20 \mu \mathrm{S} / \mathrm{cm}$ ) was higher than Handil Manarap and Handil Malintang soil (i.e. 0.15 and 0.12 $\mu \mathrm{S} / \mathrm{cm}$ respectively). Application of composted rice straws in Handil Malintang seems to stimulate the number of both atmospheric N2 fixing bacteria in this area. Roper and Ladha (1995) showed that the asymbiotic diazotrophic bacteria such as Azospirillum lipoferrum and A. brasilense was using a high mole weight carbohydrates such as $x y l a n$ (mainly component of hemisellulose) from rice straws as energy and carbon sources. In addition, differences of rice cultivars in releasing organic acid substances that can also influence presence of these bacteria. Nursyamsi (2000) reported that difference of rice cultivars produce difference of organic acid substances. The production of malic acid $(2.532 \pm 167 \mathrm{nmol} / \mathrm{g}$ dry soil) by IR 66 cultivar was higher than Cisadane rice cultivar $(1.793 \pm 153 \mathrm{nmol} / \mathrm{g}$ dry soil $)$ and succinate acids produced by IR66 was $535 \pm 153 \mathrm{nmol} / \mathrm{g}$ dry soil, but this acids was not produced by Cisadani rice cultivar.

The effectiveness of Azotobacter and Azorpirillum spp in fixing $\mathrm{N}_{2}$ atmosphere is presented in Table 1. All selected BNF isolates were able to fix atmospheric N2. Zuberer (1998) suggested that the effectiveness ranges of bacterias to fix of atmospheric $\mathrm{N}_{2}$ in their environments were from 0.04 to 0.67 nmole $\mathrm{N} / \mathrm{nmol} \mathrm{C}_{2} \mathrm{H}_{4}$. The Azotobacter isolates (i.e. 1.62-7.57 nmole N/nmole $\mathrm{C}_{2} \mathrm{H}_{4}$ ) were more effective than Azorpirillum isolates (i.e. 0.420.89 nmole $\mathrm{N} /$ nmole $\mathrm{C}_{2} \mathrm{H}_{4}$ ). The effectivity of isolates T.B.BPMT.1 and T.B.PDST.2b in fixing atmospheric $\mathrm{N} 2$ (4.07 and 2.92 nmole N/nmole $\mathrm{C}_{2} \mathrm{H}_{4}$ ) was less than Azotobacter $07.1 / \mathrm{TNH} / \mathrm{II}$, but these effectivity was more than Azotobacters. Moreover, the Azotobacter 07.1/TNH/II (i.e. 7.56 nmole $\mathrm{N} /$ nmole $\mathrm{C}_{2} \mathrm{H}_{4}$ ) was the most effective isolate in fixing atmospheric $\mathrm{N}_{2}$. 
Table 1. Effectiveness of Azotobacter Isolates and Azospirillum in Fixing Atmospheric $\mathrm{N}_{2}$

\begin{tabular}{clc}
\hline Genera & \multicolumn{1}{c}{ Isolates } & $\begin{array}{c}\text { Effectiveness } \\
(\text { nmole N/ nmol } \\
\left.\mathrm{C}_{2} \mathrm{H}_{4}\right)\end{array}$ \\
\hline \multirow{3}{*}{ Azorpirillum } & S.0.4/TNM $*$ & 0.89 \\
& S.HM.MGSR.3b & 0.42 \\
& S.TSB.BPMT.1c & 0.81 \\
& T.07.1/TNH/II * & 7.56 \\
& T.B.BPMT.1 & 4.07 \\
& T.B.MGSR.1 & 1.78 \\
& T.B.PDST.2b & 2.92 \\
& T.HM.BPMT.2b & 1.95 \\
& T.M.UNST.3 & 1.62 \\
\hline
\end{tabular}

Effectiveness $=$ sum of $\mathrm{N}$ fixed /ARA values (Zuberer, 1998)

*) Standard comparison strains from the laboratory of Soil Biotechnology, IPB

Role of Azotobacter and Azospirillum spp. in fixing atmospheric $\mathrm{N} 2$ and supplying nitrogen to rice seedling

The capability of Azotobacter and Azospirillum isolates in fixing atmospheric $\mathrm{N}_{2}$ and in supplying nitrogen to the rice seedling is shown in Figure 1. All NFB isolates when associated on IR64 rice cultivar were significantly to fix $\mathrm{N}_{2}$ atmosphere, but difference of the strains were not significantly different. We can see that its difference of $\mathrm{N}_{2}$ atmosphere amounts were fixed by NFB strains when these strains were inoculated to Siam Unus rice cultivars. Azotobacter 07,1/TNH/II; T.B.BPMT.1; T.B.PDST.2b; THM.BPMT.2b and T.M.UNST.3 and Azospirillum 04/TNM to fix of $\mathrm{N}_{2}$ atmosphere were higher than other strains i.e. 7.77 to $9.85 \mathrm{mg} \mathrm{N} /$ pot. Malarvizhi and Ladha (1999) suggested that the amount of atmospheric $\mathrm{N} 2$ fixed by isolates depend on plant needs and available of nitrogen in the soil. The increase of $\mathrm{N}$-content in the leaf tissue was also caused by different in genotype of the rice to absorb specific nutrients. Root metabolism might modify the BNF in the rhizosphere of the plant.

The ability of two bacterias genera in supplying $\mathrm{N}$ for IR64 and Siam Pandak rice cultivars at initial growth can be seen from the $\mathrm{N}$ content of the leaves (Figure 2). At the initial growth of IR64 rice cultivars, the total of $\mathrm{N}$ content was significantly increased by Azotobacter T.B.PDST.2b and THM.BPMT.2b (2.34 and $2.13 \% \mathrm{~N})$, and these values were similar to treatment with $\mathrm{N}$ fertilizer $(2.2 \% \mathrm{~N})$. At the initial growth of Siam Unus rice cultivar, only Azotobacter T.B.PDST.2b has ability to increase nitrogen content of the leaf $(1.36 \% \mathrm{~N})$, eventhough the isolate has less ability in supplying nitrogen than $\mathrm{N}$ fertilizer $(1.94 \%$ N). Dobermann and Fairhurst (2000) suggested that the optimum range of $\mathrm{N}$-tissue in rice during vegetatif growth was $2.9-4.2 \% \mathrm{~N}$, so Shrestha and Ladha (1996) found that the range $\mathrm{N}$-tissue contents in rice from 25 rice cultivars from short until long-term aged were 1.84 $-2.35 \%{ }^{15} \mathrm{~N}$.

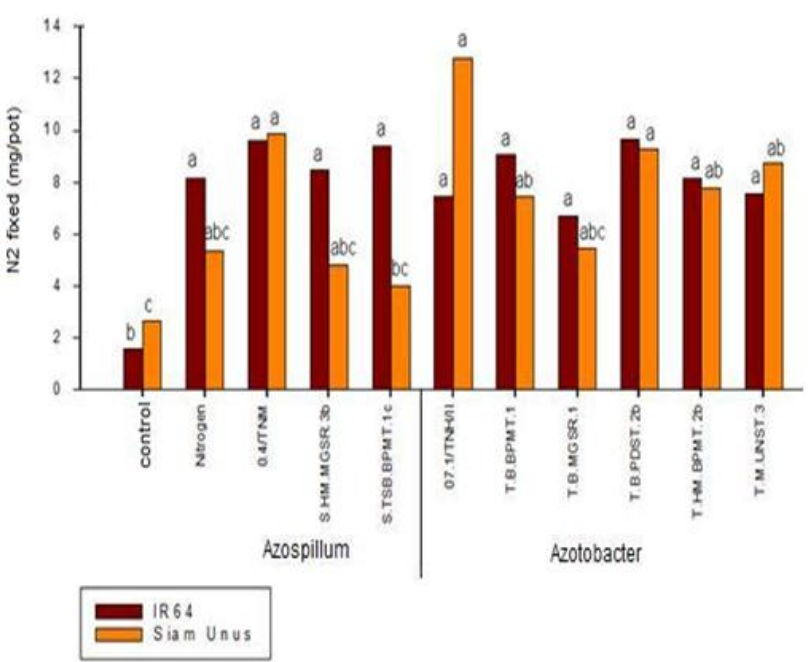

Figure 1. The Amounts of Atmospheric N2 Fixed by NFB on The Early Growth of IR64 and Siam Unus Rice Cultivars

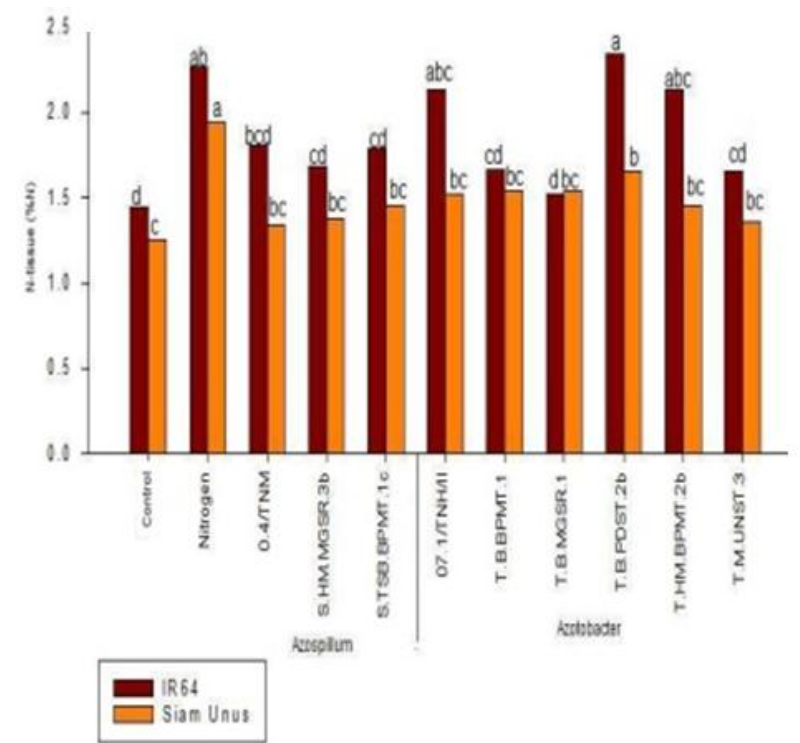

Figure 2. Nitrogen Content of The Leaf of IR64 and Siam Unus Rice Cultivars.

Role of Azotobacter spp in rice yields on tidal areas of South Kalimantan

The ability of Azotobacter isolates in increasing rice yields is presented in Figure 3 and 4. Azotobacter isolates significantly increased yield of IR64 and Margasari rice (Figure 3), but among isolates tested there were no significantly different in increasing of rice yields. Subsequently, the Azotobacter isolates which inoculated through seeds inoculations were able to increase IR64 rice yields from 1.26 ton/ha (Control) to $3.87-4.93$ ton/ha and for Margasari rice cultivar yields from 2.77 ton/ha to 4.63 -5.36 ton/ha. The yield of IR64 and Margasari inoculated with Azotobacter were the same as the IR64 and Margasari rice cultivars received Urea fertilizer. Urea treatment were able to improve rice yields up to 4-4.5 ton/ha. In Figure 4. It can be seen that Azotobacter RG.3.62 and TB.PDST.2b inoculation were significantly 
increasing yield of Siam Unus rice cultivars. The yield of Siam Unus rice cultivars inoculated with Azotobacter RG.3.62 and TB.PDST.2b were 5.17-5.92 and 5.44-6.42 ton/ha respectively.

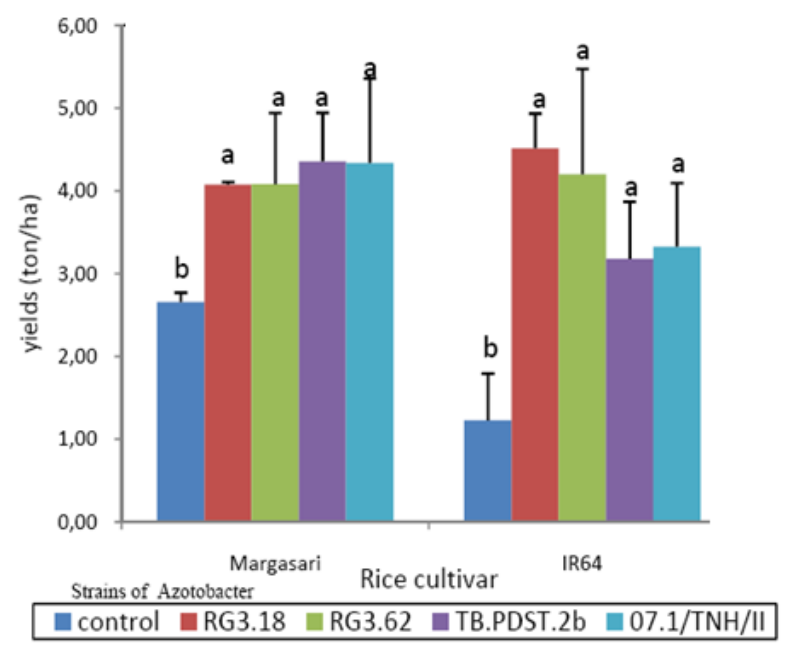

Treatment not followed the same letter(s) are statistically different at $\mathrm{p}=0,05$ (Duncan test) at each rice cultivar

Figure 3. Effect of Azotobacter Isolates Inoculation on Rice Yields of IR64 and Margasari Rice Cultivars.

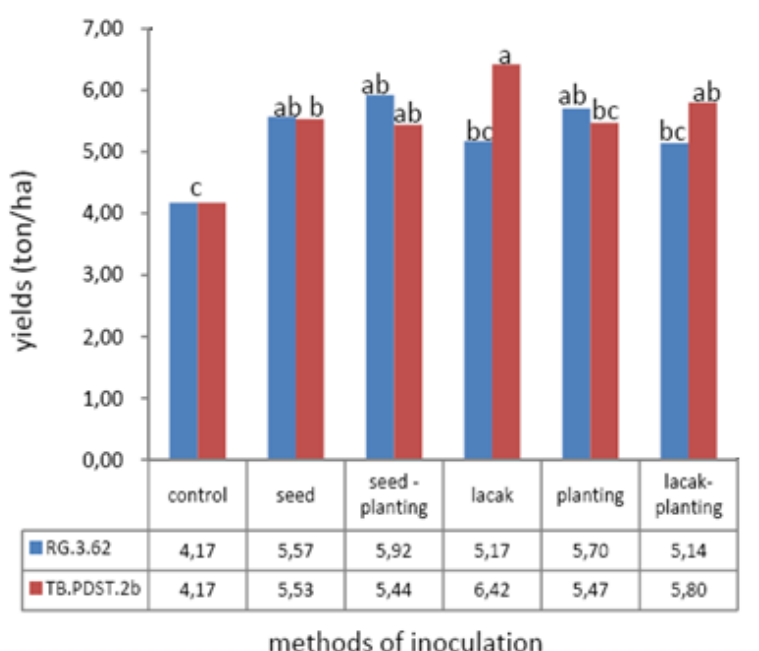

Treatments not followed the same letter(s) are statistically different at $\mathrm{p}=0,05$ (Duncan test) at each Azotobacter strain. Lacak is the 3rd transplanting of multiple transplanting methods in tidal land rice fields of South Kalimantan. Control is without inoculating

Figure 4. Effect of Azotobacter Isolates Methods on Rice Yield of Siam Unus Rice Cultivars.

\section{CONCLUSIONS}

The number of NFB isolates found on rice fields of tidal land types of South Kalimantan were varied widely. Azotobacter and Azorpirillum isolates have a high ability in fixing atmospheric $\mathrm{N}_{2}$ and in supplying $\mathrm{N}$ to rice seedlings. Azotobacter T.B.PDST.2b and T.HM.BPMT.2b were significantly supplying nitrogen for early growth of IR64 rice cultivar $(2.34$ and $2.13 \% \mathrm{~N})$. The ability of these isolates was similar to $\mathrm{N}$ fertilizer application $(2.2 \% \mathrm{~N})$. Only Azotobacter T.B.PDST.2b was relatively significant to supply $\mathrm{N}(1,36 \% \mathrm{~N})$ for Siam Unus rice seedling, even though this strain has less ability than $\mathrm{N}$ fertilizer to supply N (1,94\% N). Yield of IR64, Margasari and Siam Unus rice cultivar inoculated with Azotobacter sisolates were $3.87-4.93 ; 4.63-5.36$ and 5.44-6.42 ton/ha respectively. In conclusion, the inoculation of Azotobacter and Azorpirillum spp to rice seedling were able to substitute application of synthetic $\mathrm{N}$ fertilizer. This will reduce the risk of environment pollutions and reduce the input for rice cultivation in the tidal swamp ricefields of South Kalimantan.

\section{REFERENCES}

Anas, I. 1999. Peningkatan padi lahan rawa (gambut) satu juta hektar di Kalimantan Tengah melalui pemanfaatan mikrobe rizosfer penambat nitrogen dan pelarut fosfat. Laporan RUT 1999-2000. Kantor Menteri Negara Riset dan Teknologi. Dewan Riset Nasional. Jakarta.

Atlas, R.M. 1997. Handbook of Microbiological Media. Macmillan Publishing Co. New York.

Biswas, J.C., J.K. Ladha, and F.B. Dazzo. 2000. Rhizobia inoculation improves nutrient uptake and growth of lowland rice. Soil Sci. Soc. Am. J., 64:1644-1650.

Carley, H.E. and R.D. Watson. 1966. A new gravimetric method for estimating root-surface area. Soil sci., 102:289-291.

El-Khawas, L. and H. Adachi. 1999. Identification and quantification of auxins in culture media of Azospirillum and Klebsiella and their effect on rice roots. Biol. Fertil. Soils., 28:377-381.

IRRI. 2003. Straw and Fertilizer Management. http://www.irri.org/troprice/ depault.htm.

Malarvizhi,P., and J.K. Ladha. 1999. Influence of available nitrogen and rice genotype on associative dinitrogen fixation. Soil Sci. Soc.Am. J., 63:93-99.

Nursyamsi, D. 2000. Aluminium tolerance of tropical food crops. Division of Bioresources and Bioproduction. Thesis. Hokkaido University. Hokkaido. (unpublished).

Pratiwi, E. 1999. Karakterisasi Mutan Biosintesis Asam Indola Asetat (IAA) pada Azospirillum spp. yang Dihasilkan dari Mutagenesis Transposon. Institut Pertanian Bogor. Tesis S2 Biologi MIPA-IPB.

Roper, M.M. and J.K. Ladha. 1995. Biological $\mathrm{N}_{2}$ fixation by heterotrophic and phototrophic bacteria in association with straw. Plant Soil., 174:211-224.

Suganda, H. dan U. Kurnia. 2004. Teknologi pengendalian pencemaran lingkungan pertanian: Sekarang dan prospek penerapannya ke depan. Dalam Makalah Utama Seminar Nasional Inovasi Teknologi Pengelolaan Sumberdaya Lahan Rawa dan Pengendalian Pencemaran Lingkungan. Balai 
Penelitian Pertanian Lahan Rawa dan Loka Penelitian Pencemaran Lingkungan Pertanian. Banjarbaru 6-7 Oktober 2004.

Shrestha, R.K. and J.K. Ladha. 1996. Genotypic variation in promotion of rice dinitrogen fixation as determined by nitrogen-15 dilution. Soil Sci. Soc. Am. J. 60:1815-1821.
Zuberer, D.A. 1998. Biological Dinitrogen Fixation: Introduction and Nonsymbiotic. In Sylva, D.M., J.J. Fuhrmann, P.G. Hartel and D.A. Zuberer (Eds). Principles and Applications of Soil Microbiology. Prentice Hall, Inc. p. 295-321. 